\title{
BOARD ATTRIBUTES AND CORPORATE GOVERNANCE SOUNDNESS IN LISTED OIL AND GAS COMPANIES IN NIGERIA
}

\author{
Gift O. Eke (Ph.D) \\ Bursary Department, Rivers State University, Port Harcourt, Nigeria. \\ Email: god2much2002@yahoo.com
}

Cite this article:

Gift O. Eke (2022), Board Attributes and Corporate Governance Soundness in Listed Oil and Gas Companies in Nigeria. African Journal of Accounting and Financial Research 5(1), 14-32. DOI: 10.52589/AJAFR-123RJERI

\section{Manuscript History}

Received: 5 Jan 2022

Accepted: 29 Jan 2022

Published: 10 Feb 2022

Copyright $\odot 2022$ The Author(s). This is an Open Access article distributed under the terms of Creative Commons AttributionNonCommercial-NoDerivatives 4.0 International (CC BY-NC-ND 4.0 ), which permits anyone to share, use, reproduce and redistribute in any medium, provided the original author and source are credited.

\begin{abstract}
This study investigated the association between board attributes and corporate governance soundness in listed oil and gas companies in Nigeria. The study adopted the ex post facto research design since it was a secondary data research. The twelve (12) oil and gas companies listed on the Nigerian stock exchange between 2010 and 2018 constituted the population of the study. A census of the entire population was done since the population was small. Content analysis was used to extract data required for the study from the audited financial statements of the listed oil and gas companies that were sampled. Analysis of data was done using descriptive statistics and the hypothesis postulated was tested using correlation and multiple regression statistics. The study revealed that there is no significant association between board attributes and corporate governance soundness in listed oil and gas companies in Nigeria given the weak average coefficient of correlation of 36.8 percent. The study further revealed that board attributes influence corporate governance soundness by only 14.5 percent. Given the findings of the study, it is concluded that board attributes (board independence, board size and board meetings) correlate positively, albeit insignificantly, with corporate governance soundness. One of the recommendations made was that the board of directors of listed oil and gas companies in Nigeria should continually rally round, and be committed to involving, the various stakeholders in corporate governance in the governance process.
\end{abstract}

KEYWORDS: Board Attributes, Board of Directors, Corporate Governance, Corporate Governance Soundness. 


\section{INTRODUCTION}

Following the publication of the Cadbury report of 1992 in the United Kingdom and the enactment of the Sarbanes-Oxley Act in 2002 in the United States of American, there has been an increased focus on the board of directors as an agent of the owners of a company. The board of directors of a company is at the center of the corporate governance challenge which many business-process owners, regulatory authorities, governments around the world, academics, and researchers are still grappling with and hoping that lasting solutions can be proffered. Many of the corporate collapses and accounting scandals that the world has witnessed in the last three decades can be attributed to board room failures and board conflict of interest. It is based on this that many codes on corporate governance recommend mechanisms designed to enhance board engagements for the interest of the shareholders of a company as well as other stakeholders.

The board of directors, being charged with the governance of a company, is responsible for developing and overseeing strategies and for obligations related to accountability. In addition to overseeing the strategic direction of an entity, the board of directors fulfils responsibilities such as: assessing and managing risks that the entity is exposed to; reviewing and monitoring major plans of action; setting performance objectives; ensuring the integrity of the corporation's accounting and financial reporting systems; preparing and overseeing the implementation of annual budgets and business plans; overseeing the process of disclosure and communications; monitoring the effectiveness of the company's governance practices and making changes as needed; overseeing major capital expenditures, acquisitions and divestitures; selecting, compensating, monitoring and, when necessary, replacing key executives and overseeing succession planning; aligning key executive and board remuneration with the longer-term interests of the company and its shareholders; as well as ensuring a formal and transparent board nomination and election process (Organisation for Economic Cooperation and Development (OECD), 2004; Cadbury, 1992).

To fulfil its responsibilities effectively, the board of directors must possess certain attributes which should be in alliance with the corporate governance goal of protecting the interest of stakeholders. Board attributes are critical to the effectiveness of the board of directors of a company and relate to constructs such as the proper composition of the board, competency of board members in performing their duties, independence of the board from the company and management, appropriateness of the size of the board, active involvement of board members through attendance of meetings and questioning management decisions that appear inappropriate, appropriateness of board remuneration packages, as well as the appropriate combination of male and female members on the board. These attributes, which have become some of the major reference points and bases for corporate governance discussions and policy making, assist the board in discharging its fiduciary obligations and their non-existence or inappropriate co-existence often lead to fiduciary failures as was the case with Enron and WorldCom (Senate of the United States of America (SUSA), 2002).

Corporate governance is widely considered as the act of properly directing and controlling an organization in the interest of the organisation's various stakeholders; a sound corporate governance system should, therefore, ensure that a mutually beneficial relationship exists among the various stakeholders to a company (Cadbury, 1992; OECD, 2004; Abdullah and Page, 2009). The board of directors should typically drive the process of ensuring that a mutually beneficial relationship exists among a company's shareholders, the board of directors, 
the management, and other stakeholders through the prudent deployment of the company's resources thereby stimulating sound corporate governance. However, the failure of companies, such as Carillion, Patisserie Valerie, and British Homes Stores in 2018, irrespective of the implementation of mechanisms recommended in relevant codes of corporate governance across the world brings to question the appropriateness of suggested board attributes in ensuring corporate governance soundness. Furthermore, series of studies have been undertaken on the role of the board of directors in corporate governance, but there appear, to the best of the researcher's knowledge, to be no clear evidence on the extent to which board attributes enhance corporate governance soundness. In this study, three board attributes - board size, board independence, and board meetings - were used to investigate the association between board attributes and corporate governance soundness measured as audit committee meetings, external auditor independence and shareholders' involvement using empirical evidence from listed oil and gas companies in Nigeria.

\section{REVIEW OF RELATED LITERATURE}

\section{Board Attributes}

The board of directors of an entity is at the center of every corporate governance discussion and extant codes on corporate governance all over the world have recommended a number of attributes that the board of directors should exhibit to ensure corporate governance effectiveness. Board attributes are the characteristics of the board of directors of an entity that enable it effectively discharge its corporate governance responsibilities. Board attributes could also be described as corporate governance mechanisms designed to ensure that the board of directors act in the interest of the shareholders and other stakeholders of a company. Board characteristics or constructs are designed to reduce to a reasonable extent or eliminate (where possible) the problem associated with the separation of ownership from management; that is, the agency problem. Board of directors' attributes are designed to enable boards to either monitor management and/or provide guidance to management (Srivastava, Masli \& Sherwood, 2015). However, boards do not treat the two objectives of monitoring and guiding management as being mutually exclusive (Kim et al., 2014).

The effectiveness of the board of directors of an entity is influenced by various attributes including independence of the board from executive management, the composition of the board, size of the board, meetings held by the board, the number of male relative to female board members, chief executive officer - chairman duality, expertise or competence of the board members as well as board remuneration. Each of these attributes are discussed as follows to establish their importance in the corporate governance process.

(i) Board Independence: Board independence describes a state of freedom from influences from executive management and other directors. To be effective in fulfilling their corporate governance responsibilities, the directors should be able to exercise objective judgment in reaching their own opinion and taking decisions. The more independent the board is from executive management, the more likely it will act in the best interest of the shareholders and other stakeholders. Furthermore, an independent board will be more able to prevent and detect opportunistic behaviours by management than a dependent board. Two major mechanisms recommended by many codes of corporate governance to 
enhance board independence are: a majority of the non-executive directors on the board should be independent (that is, not have any interest in or relationship with the company), and where appropriate, the chairman of the board should be a non-executive director (Cadbury Report, 1992; OECD, 2004; Financial Reporting Council, 2010; Financial Reporting Council of Nigeria, 2016a).

(ii) Board Composition: Board composition describes the ratio of non-executive to executive directors on the board. Hence, for effectiveness in board engagements, the board should have both executive and non-executive directors and there should be a balance between the number of executive and non-executive directors. A properly constituted board ensures that no individual or small group of individuals dominates the board's decision taking (Financial Reporting Council, 2010).

(iii) Board Size: A characteristic feature of an effective board is its size. Board size is a term which describes the number of persons on the board of directors of a company in a given period, usually a year (Eke, Akpanuko \& Umoffong, 2019). It is believed that the larger the board, the more effective it becomes provided it does not become so large as to be unwieldy (Financial Reporting Council, 2010; Emile Wolf International, 2010a, 2010b; BPP Learning Media, 2010). Hence, the board should be of a sufficient size relative to the scale and complexity of the company's operations such that changes to the board's composition and that of its committees can be managed without undue disruption (Financial Reporting Council, 2010; Financial Reporting Council of Nigeria, 2016a).

(iv) Board Meetings: Board meetings is a corporate governance construct that relates to the activity level of the board of directors and implies the number of times the board meets in a year. An effective board should meet regularly to oversee the operations of the entity and appraise the performance of executive management. The frequency and quality of board meetings signifies high activity level and commitment on the part of the directors. Hence, to effectively discharge their duties, all directors should be able to allocate sufficient time to the company through attendance of meetings (Financial Reporting Council, 2010). It is widely recommended by academics and many codes of corporate governance that the board meet at least four times a year.

(v) Board Gender Diversity: Board gender diversity is the proportion of female to male directors on the board in a given year. One of the attributes of an effective board is that it has a proper combination of male and female members.

(vi) Chairman/CEO Duality: A major attribute of an effective board is the separation of the position of the chairman of the board and that of the Chief Executive Officer. This implies that the roles of chairman and chief executive officer should not be held by the same person and the chief executive officer should not go on to be the chairman of the company (Emile Wolf International, 2013). The requirement for the separation of the roles of chairman and chief executive officer by many codes of corporate governance around the world is to avoid the risk that one individual might have unfettered powers of decision and as such dominate decision making by the board.

(vii) Board Competence: To discharge their duties and responsibilities effectively, the board of directors should have a mix of skills, experience, independence and knowledge of the company. Board competence is synonymous with expertise and the ability of the board 
members; hence, board members should be properly qualified to manage (that is, direct and control) the company in the interest of the shareholders and other stakeholders. Board competence covers a broad spectrum of areas such as management and administrative expertise, financial expertise, strategy development and execution expertise, legal expertise as well as risk management expertise. To enhance the competence of the board of directors, the UK Corporate Governance Code requires all directors to receive induction on joining the board and to regularly update and refresh their skills and knowledge. Furthermore, the board should undertake a formal and rigorous annual evaluation of its own performance and that of its committees and individual directors (Financial Reporting Council, 2010).

\section{Corporate Governance Soundness}

Corporate governance is a set of relationships involving a company's shareholders, the board of directors, the management and other stakeholders (OECD, 2004). It provides the necessary structure for setting the objectives of a company, determines the means through which such objectives are attained and the basis for performance monitoring. In line with OECDs definition of corporate governance, a sound corporate governance framework ensures that the board of directors and executive management continually pursue objectives that are in the interest of the shareholders and other stakeholders and facilitates effective monitoring of those charged with governance of a company. For the purpose of this study, sound corporate governance is viewed as a framework by which organisations achieve their long term objectives through the combined efforts of the various parties to corporate governance with the directors acting as coordinators.

Apart from board attributes which have been discussed in the previous section, indicators of corporate governance soundness include:

(i) An Effective Audit Committee: An audit committee is a sub-committee of the board of directors appointed by the shareholders to provide oversight on financial reports prepared by the board of directors, oversee and monitor the risk and internal control systems of an entity and carry out investigations into any aspect of the operations of the entity that may be of interest to it. The effectiveness of an audit committee can be measured in terms of: the composition of the committee (the committee should be made up of a number of directors and representatives of the shareholders); the independence of the committee members from the board and management (for the committee to be seen to be independent, a majority, if not all, of the directors on the committee should be independent non-executive directors and the chairman of the audit committee should be an independent non-executive director (Financial Reporting Council, 2010; Financial Reporting Council of Nigeria, 2016a; Emile Wolf International, 2013); the expertise or competence of the committee (which relates to the extent of financial literacy of the committee members especially expertise in the interpretation of financial statements); and frequency and quality of meetings (the committee should meet at least four times in a year).

(ii) External Audit and External Auditor Independence: External audit is an essential element of sound corporate governance as it serves as an additional level of monitoring of the activities of those charged with the governance of an organisation. External audit is an independent examination and expression of opinion on the financial statements of 
an organisation. The primary purpose of external audit is to enable the external auditor provide reasonable assurance that the financial statements are free from material misstatements, thereby enhancing the credibility of the financial statements audited. For external audit to be effective, the external auditor should be independent of the entity being audited and of the directors. Independence as noted earlier implies that the auditor does not have any interest (financial or otherwise) in the auditee or any relationship with the directors or officers in a position to exert significant influence on the subject matter of the engagement.

(iii) Directors' Remuneration: The formulation of remuneration policies and proper management of directors' remuneration is a panacea for sound corporate governance. Remuneration of directors is a highly contentious issue and as such organisations should strive to balance the directors' compensation with the performance of the organisation and the best interest of the shareholders and other stakeholders.

(iv) Shareholders' Involvement: A sound corporate governance system should ensure that the shareholders participate actively in the affairs of the entity. According to the OECD (2004), shareholders should participate in general shareholder meetings, in decisions concerning fundamental corporate changes as well as in key corporate governance decisions, such as the nomination and election of board members.

\section{Review of Empirical Studies}

Some of the previous studies on board attributes (as independent variable) and related concepts (as dependent variable) which were reviewed are summarized in Table 1 to establish the gap in literature and justification for this current study. As can be inferred from Table 1, there appear to be no empirical study relating board attributes to corporate governance soundness; rather most of the studies relate board attributes or characteristics to concepts such as firm performance, financial reporting quality, profitability and audit quality; hence, this study is novel and significant as it relates board attributes to corporate governance soundness and establishes the association between them.

Table 1a: Summary of Empirical Literature

\begin{tabular}{|c|c|c|c|c|c|}
\hline $\begin{array}{l}\text { Author(s)/ } \\
\text { Year }\end{array}$ & Industry & $\begin{array}{l}\text { Independent } \\
\text { Variable } \\
\text { Measurement }\end{array}$ & $\begin{array}{l}\text { Dependent } \\
\text { Variable } \\
\text { Measurement }\end{array}$ & $\begin{array}{l}\text { Method(s) } \\
\text { of } \\
\text { Analysis }\end{array}$ & $\begin{array}{l}\text { Research } \\
\text { Finding(s) }\end{array}$ \\
\hline $\begin{array}{l}\text { Bathula, H. } \\
\text { (2008). }\end{array}$ & All sectors & $\begin{array}{l}\text { Board size, } \\
\text { director } \\
\text { ownership, CEO } \\
\text { duality, gender } \\
\text { diversity, } \\
\text { educational } \\
\text { qualification of } \\
\text { board members } \\
\text { and number of } \\
\text { board meetings }\end{array}$ & $\begin{array}{l}\text { Return on } \\
\text { assets. }\end{array}$ & $\begin{array}{l}\text { Generalise } \\
\text { d least } \\
\text { square. }\end{array}$ & $\begin{array}{l}\text { Only board } \\
\text { characteristics } \\
\text { such as board } \\
\text { size, CEO } \\
\text { duality and } \\
\text { gender } \\
\text { diversity were } \\
\text { found to be } \\
\text { positively } \\
\text { related with } \\
\text { firm } \\
\text { performance. }\end{array}$ \\
\hline
\end{tabular}


African Journal of Accounting and Financial Research

ISSN: 2682-6690

Volume 5, Issue 1, 2022 (pp. 14-32)

www.abjournals.org

\begin{tabular}{|c|c|c|c|c|c|}
\hline $\begin{array}{l}\text { Ferrer } \\
(2012) \text {. }\end{array}$ & Real estate. & $\begin{array}{l}\text { Board size, } \\
\text { board } \\
\text { independence, } \\
\text { duality of the } \\
\text { chairman's role } \\
\text { and } \\
\text { the chief } \\
\text { executive } \\
\text { officer's role, } \\
\text { multiple } \\
\text { directorial } \\
\text { positions, } \\
\text { managerial } \\
\text { ownership. }\end{array}$ & $\begin{array}{l}\text { Share price, } \\
\text { return on } \\
\text { equity (ROE) }\end{array}$ & $\begin{array}{l}\text { Ordinary } \\
\text { least } \\
\text { square } \\
\text { regression. }\end{array}$ & $\begin{array}{l}\text { Managerial } \\
\text { ownership } \\
\text { positively } \\
\text { influence firm } \\
\text { performance. }\end{array}$ \\
\hline $\begin{array}{l}\text { Dakhlaoui \& } \\
\text { Fredj (2020) }\end{array}$ & All sectors & $\begin{array}{l}\text { Board size, } \\
\text { board } \\
\text { independence, } \\
\text { gender diversity, } \\
\text { CEO/chairman } \\
\text { duality }\end{array}$ & ROA & $\begin{array}{l}\text { Dynamic } \\
\text { panel } \\
\text { GMM } \\
\text { estimator }\end{array}$ & $\begin{array}{l}\text { Significant } \\
\text { positive } \\
\text { relationship } \\
\text { between board } \\
\text { effectiveness } \\
\text { score and firm } \\
\text { performance. }\end{array}$ \\
\hline $\begin{array}{l}\text { Anandasayana } \\
\text { n \& } \\
\text { Velnampy } \\
(2018) .\end{array}$ & $\begin{array}{l}\text { Diversified } \\
\text { holding } \\
\text { companies. }\end{array}$ & $\begin{array}{l}\text { Board size and } \\
\text { board } \\
\text { composition. }\end{array}$ & $\begin{array}{l}\text { Return on } \\
\text { assets. }\end{array}$ & $\begin{array}{l}\text { Panel least } \\
\text { square } \\
\text { regression. }\end{array}$ & $\begin{array}{l}\text { Corporate } \\
\text { governance } \\
\text { has positive } \\
\text { and significant } \\
\text { impact on } \\
\text { corporate } \\
\text { profitability. }\end{array}$ \\
\hline
\end{tabular}


Table 1b: Summary of Empirical Literature

\begin{tabular}{|c|c|c|c|c|c|}
\hline $\begin{array}{l}\text { Author(s)/ } \\
\text { Year }\end{array}$ & Industry & $\begin{array}{l}\text { Independent } \\
\text { Variable } \\
\text { Measurement }\end{array}$ & $\begin{array}{l}\text { Dependent } \\
\text { Variable } \\
\text { Measurement }\end{array}$ & $\begin{array}{l}\text { Method(s) } \\
\text { of Analysis }\end{array}$ & $\begin{array}{l}\text { Research } \\
\text { Finding(s) }\end{array}$ \\
\hline $\begin{array}{l}\text { Saidu \& } \\
\text { Aifuwa } \\
\text { (2020). }\end{array}$ & Manufacturing. & $\begin{array}{l}\text { Board } \\
\text { independence, } \\
\text { Female board } \\
\text { gender and board } \\
\text { size }\end{array}$ & $\begin{array}{l}\text { Auditors } \\
\text { independence }\end{array}$ & $\begin{array}{l}\text { Regression } \\
\text { analysis. }\end{array}$ & $\begin{array}{l}\text { Board size has } \\
\text { positive and } \\
\text { significant } \\
\text { relationship } \\
\text { with audit } \\
\text { quality }\end{array}$ \\
\hline $\begin{array}{l}\text { Iqbal \& } \\
\text { Kakakhel } \\
\text { (2016). }\end{array}$ & Pharmaceutical. & $\begin{array}{l}\text { Board size, } \\
\text { independent } \\
\text { directors, board } \\
\text { committees and } \\
\text { board } \\
\text { remuneration }\end{array}$ & $\begin{array}{l}\text { Return on } \\
\text { assets, return } \\
\text { on equity and } \\
\text { return on sales. }\end{array}$ & $\begin{array}{l}\text { Ordinary } \\
\text { least square } \\
\text { regression. }\end{array}$ & $\begin{array}{l}\text { Board } \\
\text { characteristics } \\
\text { are positively } \\
\text { associated } \\
\text { with } \\
\text { profitability. }\end{array}$ \\
\hline $\begin{array}{l}\text { Ogbaisi, } \\
\text { Areo \& } \\
\text { Omotayo } \\
(2019) .\end{array}$ & Various & $\begin{array}{l}\text { Board expertise } \\
\text { and board } \\
\text { independence. }\end{array}$ & $\begin{array}{l}\text { Discretionary } \\
\text { accruals of } \\
\text { firms }\end{array}$ & $\begin{array}{l}\text { Ordinary } \\
\text { least square } \\
\text { regression. }\end{array}$ & $\begin{array}{l}\text { Board } \\
\text { expertise has } \\
\text { a positive } \\
\text { significant } \\
\text { relationship } \\
\text { with financial } \\
\text { reporting } \\
\text { quality while } \\
\text { board } \\
\text { independence } \\
\text { has a positive } \\
\text { insignificant } \\
\text { relationship } \\
\text { with financial } \\
\text { reporting } \\
\text { quality. }\end{array}$ \\
\hline $\begin{array}{l}\text { Akinyomi \& } \\
\text { Olutoye } \\
\text { (2015). }\end{array}$ & Banking. & $\begin{array}{l}\text { Board size and } \\
\text { directors' } \\
\text { interest. }\end{array}$ & $\begin{array}{l}\text { Return on } \\
\text { equity. }\end{array}$ & Regression. & $\begin{array}{l}\text { Positive and } \\
\text { insignificant } \\
\text { association } \\
\text { between board } \\
\text { composition, } \\
\text { board size and } \\
\text { profitability; } \\
\text { negative and } \\
\text { insignificant } \\
\text { association } \\
\text { between } \\
\text { directors' } \\
\text { interest and } \\
\text { profitability. }\end{array}$ \\
\hline
\end{tabular}


Table 1c: Summary of Empirical Literature

\begin{tabular}{|c|c|c|c|c|c|}
\hline $\begin{array}{l}\text { Author(s) } \\
\text { /Year }\end{array}$ & $\begin{array}{l}\text { Industr } \\
\mathbf{y}\end{array}$ & $\begin{array}{l}\text { Independent } \\
\text { Variable } \\
\text { Measurement }\end{array}$ & $\begin{array}{l}\text { Dependent } \\
\text { Variable } \\
\text { Measuremen } \\
\text { t }\end{array}$ & $\begin{array}{l}\text { Method(s) } \\
\text { of Analysis }\end{array}$ & $\begin{array}{l}\text { Research } \\
\text { Finding(s) }\end{array}$ \\
\hline $\begin{array}{l}\text { Oziegbe } \\
\text { \& Ogbodo } \\
(2021) .\end{array}$ & Banking & $\begin{array}{l}\text { Board gender } \\
\text { diversity, board } \\
\text { independence, board } \\
\text { meetings, board } \\
\text { remuneration and } \\
\text { board size. }\end{array}$ & $\begin{array}{l}\text { Return on } \\
\text { assets }\end{array}$ & Regression. & $\begin{array}{l}\text { All the } \\
\text { explanatory } \\
\text { variables have } \\
\text { insignificant } \\
\text { effect on firm } \\
\text { performance } \\
\text { except board } \\
\text { meetings. }\end{array}$ \\
\hline $\begin{array}{l}\text { Ghaffer } \\
\text { (2014). }\end{array}$ & Banking & $\begin{array}{l}\text { Board size and board } \\
\text { independence. }\end{array}$ & $\begin{array}{l}\text { Return on } \\
\text { assets and } \\
\text { return on } \\
\text { equity. }\end{array}$ & Regression. & $\begin{array}{l}\text { Significant } \\
\text { relationship } \\
\text { between } \\
\text { dependent and } \\
\text { independent } \\
\text { variables. }\end{array}$ \\
\hline $\begin{array}{l}\text { Ayodele, } \\
\text { Aderemi, } \\
\text { Obigbemi } \\
\& \text { Ojeka } \\
(2016) .\end{array}$ & $\begin{array}{l}\text { Oil and } \\
\text { gas. }\end{array}$ & $\begin{array}{l}\text { Board composition, } \\
\text { audit committee, } \\
\text { board size and } \\
\text { corporate governance } \\
\text { disclosure. }\end{array}$ & $\begin{array}{l}\text { Return on } \\
\text { equity, profit } \\
\text { margin and } \\
\text { return on } \\
\text { asset. }\end{array}$ & $\begin{array}{l}\text { Correlation } \\
\text { and } \\
\text { regression } \\
\text { analysis. }\end{array}$ & $\begin{array}{l}\text { Positive } \\
\text { relationship } \\
\text { between board } \\
\text { composition } \\
\text { and financial } \\
\text { performance. }\end{array}$ \\
\hline
\end{tabular}

\section{METHODOLOGY}

The ex post facto research design was adopted for this study considering that the study is a secondary data research. All the twelve (12) oil and gas companies listed on the Nigerian Stock Exchange constituted the population and sample size of the study. Panel data covering the period 2010 to 2018 were obtained from the audited financial statements and annual reports of the listed oil and gas companies and from the Nigerian Stock Exchange fact book using content analysis. Descriptive data analysis was done using percentages, mean and standard deviation. Correlation and multiple regression analyses were used in this study to investigate the association between board attributes and corporate governance soundness as well as the influence of board attributes on corporate governance soundness in listed oil and gas companies in Nigeria. The relationship between board attributes and corporate governance soundness is expressed in functional form as follows:

$$
\mathrm{CGS}=f(\mathrm{BA}+\varepsilon)
$$

Where:

CGS $=$ Corporate Governance Soundness

BA = Board Attributes

$\varepsilon=$ Error Term 
Specifically, three econometric models were used to investigate the association between board attributes and corporate governance soundness in listed oil and gas companies in Nigeria. The models are:

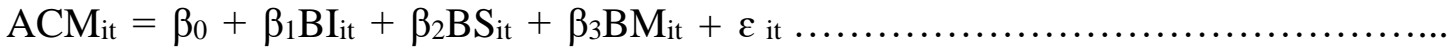

$$
\begin{aligned}
& \text { Model } 1
\end{aligned}
$$

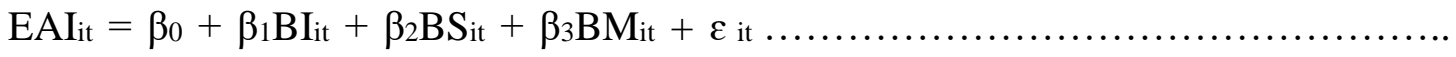

$$
\begin{aligned}
& \text { Model } 2 \\
& \mathrm{SI}_{\text {it }}=\beta_{0}+\beta_{1} \mathrm{BI}_{\mathrm{it}}+\beta_{2} \mathrm{BS}_{\mathrm{it}}+\beta_{3} \mathrm{BM}_{\mathrm{it}}+\varepsilon \text { it } \\
& \text { Model } 3
\end{aligned}
$$

Where:

$\mathrm{ACM}=$ Audit Committee Meetings.

$\mathrm{EAI}=$ External Auditor Independence.

$\mathrm{SI}=$ Shareholders' Involvement

$\mathrm{BI}=$ Board Independence

$\mathrm{BS}=$ Board Size

$\mathrm{BM}=$ Board Meetings

$\beta_{0}=$ Intercept

$\beta_{1}, \beta_{2}, \beta_{3}=$ Regression coefficients of the independent variables

$\varepsilon=$ Error Term

$\mathrm{i}=$ Number of companies

$\mathrm{t}=$ Time period (in years).

Table 2 presents a summary of the variables and their measurement. 
Table 2: Description and Measurement of Variables

\begin{tabular}{|c|c|c|c|}
\hline Variable & Symbol & Variable Type & Measurement \\
\hline $\begin{array}{l}\text { Board } \\
\text { Independence. }\end{array}$ & $\mathrm{BI}$ & Independent. & $\begin{array}{l}\text { This was measured as the proportion of } \\
\text { independent non-executive directors to } \\
\text { the total number of directors on the } \\
\text { board, that is, number of independent } \\
\text { non-executive directors divided by the } \\
\text { total number of directors. }\end{array}$ \\
\hline Board Size. & $\mathrm{BS}$ & Independent. & $\begin{array}{l}\text { This was measured as the total number } \\
\text { of persons on the board of directors in a } \\
\text { given year. }\end{array}$ \\
\hline Board Meetings. & $\mathrm{BM}$ & Independent. & $\begin{array}{l}\text { This was measured as the total number } \\
\text { of meetings held by the board of } \\
\text { directors in a given year. }\end{array}$ \\
\hline $\begin{array}{l}\text { Audit Committee } \\
\text { Meetings. }\end{array}$ & $\mathrm{ACM}$ & Dependent. & $\begin{array}{l}\text { This was measured as the total number } \\
\text { of meetings held by the audit committee } \\
\text { in a given year. }\end{array}$ \\
\hline $\begin{array}{l}\text { External Auditor } \\
\text { Independence. }\end{array}$ & EAI & Dependent. & $\begin{array}{l}\text { This was measured as one (1) where the } \\
\text { audit firm engaged by the company is } \\
\text { one of the "big four" firms; otherwise it } \\
\text { was measured as zero. }\end{array}$ \\
\hline $\begin{array}{l}\text { Shareholders' } \\
\text { Involvement. }\end{array}$ & SI & Dependent. & $\begin{array}{l}\text { This was measured as total number of } \\
\text { shareholders in a given year. }\end{array}$ \\
\hline
\end{tabular}

\section{EMPIRICAL RESULTS AND DISCUSSION OF FINDINGS}

\section{Descriptive Statistics}

Table 3 displays the descriptive statistics for all the proxies of the independent and dependent variables so that patterns can be identified and inferences drawn.

Table 3: Descriptive statistics

\begin{tabular}{lccccccc}
\hline & $\mathrm{N}$ & Range & $\begin{array}{c}\text { Minimu } \\
\mathrm{m}\end{array}$ & $\begin{array}{c}\text { Maximu } \\
\mathrm{m}\end{array}$ & Mean & $\begin{array}{c}\text { Std. } \\
\text { Deviation } \\
\text { Statistic }\end{array}$ & Sariance \\
& $\begin{array}{c}\text { Statististic } \\
\mathrm{c}\end{array}$ & $\begin{array}{c}\text { Statisti } \\
\mathrm{c}\end{array}$ & $\begin{array}{c}\text { Statistic } \\
\text { Statistic }\end{array}$ & $\begin{array}{c}\text { Statisti } \\
\mathrm{c}\end{array}$ & & & \\
\hline Board Independence & 90 & 71 & 0 & 71 & 27.52 & 17.592 & 309.495 \\
Board Size & 90 & 8 & 4 & 12 & 8.49 & 2.100 & 4.410 \\
Board Meetings & 90 & 12 & 1 & 13 & 4.70 & 1.487 & 2.212 \\
$\begin{array}{l}\text { Audit Committee } \\
\text { Meetings }\end{array}$ & 90 & 4 & 2 & 6 & 4.02 & .687 & .471 \\
$\begin{array}{l}\text { External Auditor } \\
\text { Independence }\end{array}$ & 90 & 1 & 0 & 1 & .73 & .445 & .198 \\
$\begin{array}{l}\text { Shareholders' } \\
\text { Involvement }\end{array}$ & 90 & 273 & 1 & 274 & 92.44 & 96.758 & 9362.13 \\
Valid N (listwise) & 90 & & & & & & 7 \\
\hline
\end{tabular}


Table 3 reveals that 27.52 percent of the board of directors of listed oil and gas companies in Nigeria were independent during the period covered by this study (2010 to 2018). Thus, on the average, the board of directors of listed oil and gas companies in Nigeria were not substantially made up of independent non-executive directors as required by extant corporate governance codes. The result also indicates that, on the average, listed oil and gas companies in Nigeria maintained a board size of eight (8) members during the period covered by this study. Furthermore, the board of the listed oil and gas companies sampled held an average of five (5) meetings per annum during the period covered by this study, given the mean statistic of 4.7 shown in Table 3.

During the period covered by this study, the audit committees of the listed oil and gas companies sampled held an average of four (4) meetings annually with some of them having as much as six (6) meetings and some others having just two (2) meetings per annum. A majority of the external auditors of the listed oil and gas companies sampled were big four audit firms and were considered independent (given the mean of 73 percent). Table 3 also indicates that, on the average, listed oil and gas companies in Nigeria had 92 shareholders in their register.

\section{Correlation and Regression Analysis}

Correlation and multiple linear regression statistical techniques were used in this study to establish the association between board attributes and corporate governance soundness as well as the influence of board attributes on corporate governance soundness in listed oil and gas companies in Nigeria. The hypothesis for this study, stated in the null form, is:

$\mathrm{H}_{\mathrm{o}}$ : There is no significant association between board attributes and corporate governance soundness in listed oil and gas companies in Nigeria.

The decision rule is based on the significance of the coefficient of correlation $(r)$ and coefficient of determination $\left(r^{2}\right)$ values obtained. Hence, the hypothesis is rejected where the computed $r$ value is greater than 0.5 at $5 \%$ level of significance. The results of the correlation and multiple regression tests are presented in Table 4 and Table 5.

Table 4: Bivariate Correlation for Board Attributes and Corporate Governance Variables

\begin{tabular}{|c|c|c|c|c|c|c|c|}
\hline & & BI & BS & BM & ACM & EA & SI \\
\hline & Pearson Correlation & 1 & -.072 & -.053 & .097 & .108 & $-.418^{* * *}$ \\
\hline \multirow[t]{3}{*}{ BI } & Sig. (2-tailed) & & .500 & .623 & .363 & .311 & .000 \\
\hline & $\mathrm{N}$ & 90 & 90 & 90 & 90 & 90 & 90 \\
\hline & Pearson Correlation & -.072 & 1 & $.425^{* *}$ & .055 & .081 & .104 \\
\hline \multirow[t]{3}{*}{ BS } & Sig. (2-tailed) & .500 & & .000 & .608 & .448 & .328 \\
\hline & $\mathrm{N}$ & 90 & 90 & 90 & 90 & 90 & 90 \\
\hline & Pearson Correlation & -.053 & $.425^{* *}$ & 1 & $.403^{* *}$ & .200 & -.035 \\
\hline \multirow[t]{3}{*}{ BM } & Sig. (2-tailed) & .623 & .000 & & .000 & .058 & .743 \\
\hline & $\mathrm{N}$ & 90 & 90 & 90 & 90 & 90 & 90 \\
\hline & Pearson Correlation & .097 & .055 & $.403^{* *}$ & 1 & -.054 & .082 \\
\hline \multirow[t]{2}{*}{$\mathrm{ACM}$} & Sig. (2-tailed) & .363 & .608 & .000 & & .613 & .445 \\
\hline & $\mathrm{N}$ & 90 & 90 & 90 & 90 & 90 & 90 \\
\hline EAI & Pearson Correlation & .108 & .081 & .200 & -.054 & 1 & $-.516^{* *}$ \\
\hline
\end{tabular}




\begin{tabular}{llrrrrrr} 
& Sig. (2-tailed) & .311 & .448 & .058 & .613 & & .000 \\
& $\mathrm{~N}$ & 90 & 90 & 90 & 90 & 90 & 90 \\
& Pearson Correlation & $-.418^{* *}$ & .104 & -.035 & .082 & $-.516^{* * *}$ & 1 \\
SI & .000 & .328 & .743 & .445 & .000 & \\
& Sig. (2-tailed) & 90 & 90 & 90 & 90 & 90 & 90 \\
\hline **. Correlation is significant at the 0.05 level (2-tailed).
\end{tabular}

Table 4 displays the result of the bivariate correlation analysis performed to determine the association between board attributes (measured as board independence, board size and board meetings) and corporate governance soundness (measured as audit committee meetings, external auditor independence and shareholders' involvement). The result indicates that each of the measures of board attributes is positively correlated with the corresponding measures of corporate governance soundness. However, not all the independent variables showed statistically significant correlation with the corresponding dependent variables. The correlation between board independence and shareholders' involvement is statistically significant $(\mathrm{r}=$ $0.418, \mathrm{p}<0.05)$. In the same vein, the correlation between board meetings and audit committee meetings is statistically significant $(r=0.403, \mathrm{p}<0.05)$.

Table 5: Multiple Regression Analysis of Board Attributes and Corporate Governance Soundness

\begin{tabular}{ccccc}
\hline \multicolumn{5}{c}{ Model Summary } \\
\hline Model & $\mathrm{R}$ & $\mathrm{R}$ Square & Adjusted R Square & $\begin{array}{c}\text { Std. Error of the } \\
\text { Estimate }\end{array}$ \\
\hline 1 & $.437^{\mathrm{a}}$ & .191 & .163 & .628 \\
2 & $.233^{\mathrm{a}}$ & .054 & .021 & .440 \\
3 & $.435^{\mathrm{a}}$ & .189 & .161 & 88.616 \\
\hline
\end{tabular}

a. Predictors: (Constant), BOARD MEETINGS, BOARD INDEPENDENCE, BOARD SIZE

The results displayed in Table 5 reveals that, in respect of model 1 (which tests the relationship between board attributes and audit committee meetings), the coefficient of correlation ( $r$ ) is 0.437 and the coefficient of determination $\left(\mathrm{r}^{2}\right)$ is 0.191 at $5 \%$ level of significance. The correlation coefficient of $43.7 \%$ indicates a positive linear relationship and fair degree of correlation between board attributes and audit committee meetings. The coefficient of determination, on the other hand, indicates that $19.1 \%$ of the meetings held by the audit committee of the quoted oil and gas companies sampled was influenced by board attributes (measured as board independence, board size, board meetings) while $80.9 \%$ was due to other factors.

In respect of model 2 (which tests the relationship between board attributes and external auditor independence), the coefficient of correlation ( $\mathrm{r}$ ) is 0.233 and the coefficient of determination $\left(\mathrm{r}^{2}\right)$ is 0.054 at $5 \%$ level of significance. The correlation coefficient of $23.3 \%$ indicates a positive linear relationship and slightly weak correlation between board attributes and external auditor independence. The coefficient of determination, on the other hand, indicates that $5.4 \%$ 
of the external auditors' independence was influenced by board attributes (measured as board independence, board size, board meetings) while $94.6 \%$ was due to other factors.

In respect of model 3 (which tests the relationship between board attributes and shareholders' involvement), the coefficient of correlation ( $\mathrm{r}$ ) is 0.435 and the coefficient of determination $\left(\mathrm{r}^{2}\right)$ is 0.189 at $5 \%$ level of significance. The correlation coefficient of $43.5 \%$ indicates a positive linear relationship and fair degree of correlation between board attributes and shareholders' involvement. The coefficient of determination, on the other hand, indicates that board attributes (measured as board independence, board size, board meetings) affects shareholders' involvement by $18.9 \%$ while $81.1 \%$ is due to other factors.

The average coefficient of correlation for the three proxies for corporate governance soundness from Table 5 is $36.8 \%$ (that is, $43.7+23.3+43.5$ divided by 3 ). This result supports the hypothesis that there is no significant association between board attributes and corporate governance soundness in listed oil and gas companies in Nigeria; thus, the hypothesis is accepted.

\section{DISCUSSION OF FINDINGS}

The board of directors are charged with the governance of an organisation and as such serve as a rallying point for the proper direction and control of an organisation. To fulfil its responsibility for the governance of an entity and to ensure corporate governance effectiveness, the board of directors is required to exhibit a number of attributes which include proper board composition, chairman/chief executive officer duality, gender diversity, competence, board size, board independence, accountability as well as board meetings. These attributes are believed to influence corporate governance success and the role the other parties to corporate governance play in the governance process. Considering the importance of audit committee, the external auditor and shareholders in the governance process, this study used three board attributes (board independence, board size and board meetings) to investigate the association between board attributes and corporate governance soundness (represented by audit committee meetings, external auditor independence and shareholders' involvement) in listed oil and gas companies in Nigeria.

Contrary to the researcher's a priori expectation, the study found that there is no significant association between board attributes and corporate governance soundness in listed oil and gas companies in Nigeria given the weak average coefficient of correlation of 36.8 percent. This indicates that board attributes do not significantly shape the frequency and quality of audit committee meetings, external auditor independence and shareholders' involvement which are very essential for corporate governance soundness. Furthermore, the average coefficient of determination of $14.466(19.1+5.4+18.9$ divided by 3$)$ indicates that board attributes influence corporate governance soundness by only 14.5 percent. Thus, corporate governance soundness does not significantly depend on board attributes but is a product of board efforts, managerial involvement and contribution, audit committee engagements and oversight activities, external audit effectiveness, internal audit engagements, shareholders' active involvement, employees' contribution and commitment as well as external regulatory influence. Hence, non-board related attributes account for $85.5 \%$ (that is, $100-14.5$ ) of 
corporate governance soundness in listed oil and gas companies in Nigeria, as empirically established in this study.

\section{CONCLUSION AND RECOMMENDATIONS Conclusion}

The board of directors of listed oil and gas companies in Nigeria exhibit the major attributes required for effective corporate governance and these attributes (board independence, board size and board meetings) correlate positively, albeit insignificantly, with audit committee meetings, external auditor independence and shareholders' involvement which are essential ingredients for corporate governance soundness. The results of this study provide a level of comfort that the board of directors are essential for corporate governance effectiveness; however, ultimate success in the governance of an entity lies in the cumulative effect of the efforts of major stakeholders such as the board, executive management, audit committee, external auditors, internal auditors, shareholders, employees and external regulatory authorities.

\section{Recommendations}

Based on the findings and conclusion of this study, the following recommendations are advanced:

(i) To improve significantly the positive contribution of the board of directors to corporate governance soundness, the board of directors of listed oil and gas companies in Nigeria should continually rally round, and be committed to involving, the various stakeholders in corporate governance in the governance process. This is very essential as no corporate governance effort will be successful without the combined effort of all relevant stakeholders.

(ii) In addition to being independent, having appropriate board size and holding regular meetings, boards of directors of listed oil and gas companies in Nigeria should fully implement the requirements of the Nigerian code of corporate governance, the UK code of corporate governance as well as the OECD principles of corporate governance relating to board engagements.

\section{REFERENCES}

Abdullah, A. \& Page, M. (2009). Corporate Governance and Corporate Performance: UK FTSE 350 Companies. The Institute of Chartered Accountants of Scotland, Edinburgh.

Akinyomi, O.J. \& Olutoye, E.A. (2015). Corporate Governance and Profitability of Nigerian Banks. Asian Journal of Finance and Accounting, 7(1), 172 - 182.

Anandasayanan, S. \& Velnampy, T. (2018). Corporate Governance and Corporate Profitability of Listed Diversified Holding Companies in Sri Lanka. International Journal of Accounting and Financial Reporting, 8(1), 294 - 304.

Ayodele, S., Aderemi, A.K., Obigbemi, I.F. \& Ojeka, S.A. (2016). Assessing the Connectedness between Corporate Governance Mechanisms and Financial Performance 
of Listed Oil and Gas Companies in Nigeria. Journal of Accounting, Finance

and Auditing Studies, 2(4), 155 - 171.

Bathula, H. (2008). Board characteristics and firm performance: Evidence from New Zealand. (PhD Thesis). Auckland University of Technology, New Zealand.

BPP Learning Media (2010). Audit and Assurance: International. BPP Learning Media Ltd, London.

Cadbury Report (1992). The Financial Aspects of Corporate Governance. Gee Publishing Ltd., London.

Dakhlaoui, M. \& Fredj, I. (2020). Board attributes and firm performance: Tunisian evidence. IBIMA Business Review, 2020, 1 - 18, DOI: 10.5171/2020.557928.

Eke, G.O. Akpanuko, E.E. \& Umoffong, J.N. (2019). Corporate governance and profitability of quoted oil and gas companies in Nigeria. International Journal of Business and Management Review, 7(8), $97-124$.

Emile Wolf International (2010a). Audit and Assurance: UK stream. Emile Wolf Publishing Ltd, Berkshire.

Emile Wolf International (2010b). Advanced audit and Assurance: International. Emile Wolf Publishing Ltd, Berkshire.

Emile Wolf International (2013). Governance, risk and ethics. Emile Wolf Publishing Ltd, Berkshire.

Ferrer, R. C. (2012). The influence of corporate board characteristics on firm performance of

Financial Reporting Council (2010). The UK Corporate Governance Code. Financial Reporting Council Limited, London.

Financial Reporting Council of Nigeria (2016a). National Code of Corporate Governance. Available at http/financialreportingcouncil.gov.ng (Retrieved August 10, 2017).

Ghaffer, A. (2014). Corporate Governance and Profitability of Islamic Banks Operating in Pakistan. Interdisciplinary Journal of Contemporary Research in Business, 6(2), 320336.

Iqbal, K. \& Kakakhel, S.J. (2016). Corporate Governance and its Impact on Profitability of the Pharmaceutical Industry in Pakistan. Journal of Management Science, January June, $73-82$.

Kim, K., Mauldin, E. \& Patro, S. (2014). Outside directors and board advising and monitoring

Ogbaisi, S.A., Areo, A.B. \& Omotayo, V.A. (2019). Board attributes and quality of financial reporting in Nigerian companies: An empirical evidence. Malaysian E-Commerce Journal, 3(2), $1-5$.

Organisation for Economic Cooperation and Development (2004). OECD Principles of Corporate Governance. OECD Publications Service, Paris.

Oziegbe, D.J. \& Ogbodo, O. (2021). Board attributes and firm performance of Nigerian quoted banks with international authorization. International Journal of Economics,

Business and Management Research, 5(7), 302 - 317.

performance. Journal of Accounting and Economics, 57(2), 110 - 131.

publicly listed property companies in the Philippines. Academy of Accounting and Financial Studies Journal, 16(4), 123 - 142.

Saidu, M. \& Aifuwa, H.O. (2020). Board characteristics and audit quality:the moderating role of gender diversity. International Journal of Business and Law Research, 8(1), 144 155 .

Senate of the United States of America (2002). The role of the board of directors in Enron's collapse: Report Prepared by the Permanent Subcommittee on Investigations of the Senate of the United States. Washington: United States Government Printing Office. 
African Journal of Accounting and Financial Research

ISSN: 2682-6690

Volume 5, Issue 1, 2022 (pp. 14-32)

www.abjournals.org

Srivastava, R.P., Masli, A. \& Sherwood, M.G. (2015). Attributes and structure of an effective board of directors: A theoretical investigation. Available at https://www.wichita.edu/academics/ business/accountancy/documents/Srivastava_et_al_BOD_-_3_15_2015.pdf. (Retrieved 23 August, 2019). 


\section{APPENDIX}

\section{FURTHER REGRESSION RESULTS}

\section{Model 1}

ANOVA ${ }^{a}$

\begin{tabular}{|c|c|c|c|c|c|c|}
\hline \multicolumn{2}{|c|}{ Model } & $\begin{array}{l}\text { Sum of } \\
\text { Squares }\end{array}$ & $\mathrm{df}$ & $\begin{array}{l}\text { Mean } \\
\text { Square }\end{array}$ & $\mathrm{F}$ & Sig. \\
\hline \multirow{3}{*}{1} & Regression & 8.019 & 3 & 2.673 & 6.773 & $.000^{\mathrm{b}}$ \\
\hline & Residual & 33.937 & 86 & .395 & & \\
\hline & Total & 41.956 & 89 & & & \\
\hline
\end{tabular}

a. Dependent Variable: AUDIT COMMITTEE MEETINGS

b. Predictors: (Constant), BOARD MEETINGS, BOARD INDEPENDENCE, BOARD SIZE

\section{Coefficients $^{\mathbf{a}}$}

\begin{tabular}{|c|c|c|c|c|c|c|}
\hline \multirow{2}{*}{\multicolumn{2}{|c|}{ Model }} & \multicolumn{2}{|c|}{$\begin{array}{l}\text { Unstandardized } \\
\text { Coefficients }\end{array}$} & $\begin{array}{c}\text { Standardized } \\
\text { Coefficients }\end{array}$ & \multirow[t]{2}{*}{$\mathrm{t}$} & \multirow[t]{2}{*}{ Sig. } \\
\hline & & $\mathrm{B}$ & Std. Error & Beta & & \\
\hline \multirow{4}{*}{1} & (Constant) & 3.267 & .323 & & 10.126 & .000 \\
\hline & BOARD & .004 & .004 & .112 & 1.148 & .254 \\
\hline & BOARD SIZE & -.044 & .035 & -.135 & -1.262 & .210 \\
\hline & BOARD MEETINGS & .215 & .049 & .466 & 4.349 & .000 \\
\hline
\end{tabular}

a. Dependent Variable: AUDIT COMMITTEE MEETINGS

\section{Model 2}

ANOVA ${ }^{a}$

\begin{tabular}{|c|c|c|c|c|c|c|}
\hline \multicolumn{2}{|c|}{ Model } & $\begin{array}{l}\text { Sum of } \\
\text { Squares }\end{array}$ & df & $\begin{array}{l}\text { Mean } \\
\text { Square }\end{array}$ & $\mathrm{F}$ & Sig. \\
\hline \multirow{3}{*}{1} & Regression & .955 & 3 & .318 & 4.644 & $.045^{\mathrm{b}}$ \\
\hline & Residual & 16.645 & 86 & .194 & & \\
\hline & Total & 17.600 & 89 & & & \\
\hline
\end{tabular}

a. Dependent Variable: EXTERNAL AUDITOR INDEPENDENCE

b. Predictors: (Constant), BOARD MEETINGS, BOARD INDEPENDENCE, BOARD SIZE 


\section{Coefficients $^{\mathrm{a}}$}

\begin{tabular}{|c|c|c|c|c|c|c|}
\hline \multirow{2}{*}{\multicolumn{2}{|c|}{ Model }} & \multicolumn{2}{|c|}{$\begin{array}{c}\text { Unstandardized } \\
\text { Coefficients }\end{array}$} & $\begin{array}{c}\text { Standardized } \\
\text { Coefficients }\end{array}$ & \multirow[t]{2}{*}{$\mathrm{t}$} & \multirow[t]{2}{*}{ Sig. } \\
\hline & & B & Std. Error & Beta & & \\
\hline \multirow{4}{*}{1} & (Constant) & .358 & .226 & & 1.583 & .045 \\
\hline & BOARD & .003 & .003 & .119 & 1.130 & .262 \\
\hline & BOARD SIZE & .000 & .025 & .002 & .018 & .986 \\
\hline & BOARD MEETINGS & .062 & .035 & .206 & 1.776 & .079 \\
\hline
\end{tabular}

a. Dependent Variable: EXTERNAL AUDITOR INDEPENDENCE

\section{Model 3}

ANOVA ${ }^{a}$

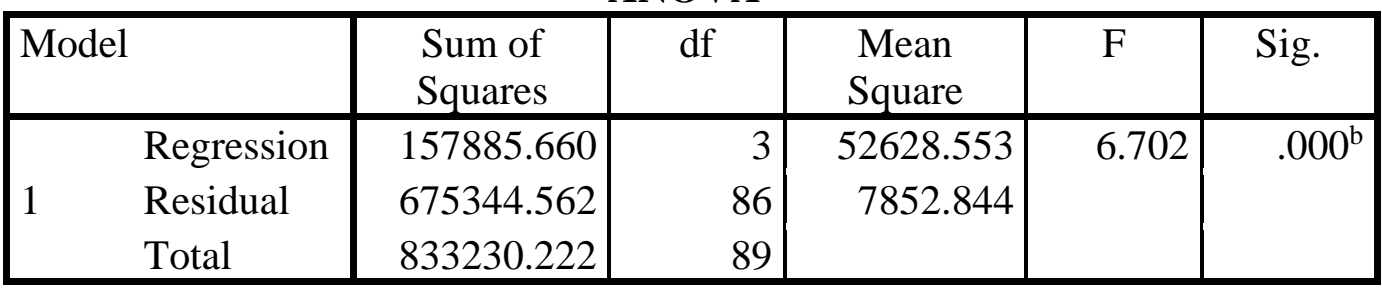

a. Dependent Variable: SHAREHOLDERS' INVOLVEMENT

b. Predictors: (Constant), BOARD MEETINGS, BOARD INDEPENDENCE, BOARD SIZE

\section{Coefficients $^{\mathrm{a}}$}

\begin{tabular}{|c|c|c|c|c|c|c|}
\hline \multirow{2}{*}{\multicolumn{2}{|c|}{ Model }} & \multicolumn{2}{|c|}{$\begin{array}{c}\text { Unstandardized } \\
\text { Coefficients }\end{array}$} & $\begin{array}{c}\text { Standardized } \\
\text { Coefficients }\end{array}$ & \multirow[t]{2}{*}{$\mathrm{t}$} & \multirow[t]{2}{*}{ Sig. } \\
\hline & & $\mathrm{B}$ & Std. Error & Beta & & \\
\hline \multirow{4}{*}{1} & (Constant) & 141.155 & 45.509 & & 3.102 & .003 \\
\hline & $\begin{array}{l}\text { BOARD } \\
\text { INDEPENDENCE }\end{array}$ & -2.281 & .535 & -.415 & -4.259 & .000 \\
\hline & BOARD SIZE & 5.541 & 4.949 & .120 & 1.120 & .266 \\
\hline & BOARD MEETINGS & -7.019 & 6.979 & -.108 & -1.006 & .317 \\
\hline
\end{tabular}

a. Dependent Variable: SHAREHOLDERS' INVOLVEMENT 